\title{
脳梁梗塞患者のリハビリテーション
}

\author{
渡邊修*1 宮野佐年*1 杉下守弘*2 \\ 上久保 毅*1 菅原 光晴*1
}

\section{Rehabilitation of a Case with almost Complete Infarction of the Corpus Callosum}

\author{
Shu Watanabe, ${ }^{* 1}$ Satoshi Miyano, ${ }^{* 1}$ Morihiro Sugishita, ${ }^{* 2}$ \\ Takeshi Kamikubo, ${ }^{* 1}$ Mitsuharu Sugawara*1
}

\begin{abstract}
We report on a 51-year-old right-handed man with an ischemic infarction affecting the almost total length of the corpus callosum except the rostrum portion. After akinetic mutism in an acute period, he developed compulsive grasp of objects with the right hand, and ideomotor apraxia in left hand. Moreover, he presented left tactile anomia, left hemispatial neglect with the right hand and alexia in the left visual fields. Performance intelligence quotient (PIQ) with the right hand showed 47 and that with the left hand 72. To reduce motor disturbance of both hands, enough relaxation before motion was effective. In order to avoid interference of the left hand with the right hand, the patient sometimes fixed left hand. Ideomotor apraxia in left hand was worsened without visual feedback. (Jpn J Rehabil Med 2001; 38 : 465-470)

要 旨：脳梁が選択的に梗塞を起こす例はきわめて稀である. 本症例が呈する両上肢の異な る運動障害に対しリハビリテーションを進めるとともに，各種の神経心理学的検査を施行した ので, 従来の分離脳研究から得られた知見をもとに考察した。症例は 51 歳男性. 右利き.急 性期の一時的な無動性無言の後, 右上肢の強迫的道具使用および左手の観念運動失行が問題と なりリハビリテーション目的の入院となった。さらに右上肢での左半側無視，左手の触覚認 知, 呼称障害, 左視野での失読を認め, WAIS-R における動作性知能指数は右手使用で 47 , 左手使用で 72 であった。一方, 両上肢の運動障害に対しては, 動作時に充分リラクゼーショ ンを図ること, 左手を机の柱に握らせること, 習得した動作を中心に行うこと, 視覚的フィー ドバックを重視することが重要であると思われた。（リハ医学 2001；38：465-470)
\end{abstract}

Key words: 脳梁 (corpus callosum), 梗塞 (infarction), 分離脳 (split brain), リハビ リテーション (rehabilitation)

\section{はじめに}

脳梁が選択的に梗塞を起こす例はきわめて稀であ

る.我々は，吻部と膝部をわずかに残し，その後方の 脳梁が全域にわたって損傷をきたした梗塞例を経験し た. 脳梁の病巣が前後に広汎に及ぶと, 左右の大脳半
球を大きく離断することから，両上肢はそれぞれ異な る運動を呈し日常生活に支障となる。本症例に対し， リハビリテーション（以下，リハ）を進める中で，各 種, 神経心理学的検査を施行したので, リハの経過と あわせて報告したい。

2000 年 12 月 19 日受付, 2001 年 4 月 6 日受理

*1 東京慈恵会医科大学リハビリテーション科/テ 201-0003 東京都狛江市和泉本町 4-11-1

Department of Rehabilitation Medicine, Jikei University School of Medicine

*2 東京大学大学院医学系研究科認知・言語神経科学/ $=113-8655$ 東京都文京区本郷 7-3-1

Department of Cognitive Neuroscience, Faculty of Medicine, University of Tokyo 


\section{症例}

51 歳, 男性.

1. 主 訴：左右の上肢が異なる運動をするので困 る.

2. 既往歴： 3 年前から高血圧，糖尿病を指摘され 治療を受けていた。

3. 現病歴：平成 12 年 2 月 8 日, 仕事中に右下肢 の脱力を自覚し, 2 時間後に頭痛とともに右上肢の軽 い麻痺が出現し，近医に入院となった．入院後，右上 下肢の中枢性運動麻痺が進行し，発語も全くなくなっ たが意識は清明であった. 脳梁と左帯状回の脳梗塞の 診断のもと, 保存的治療が行われた. 1 週間後から, 発語とともに中枢性運動麻痺の回復をみた。独歩が可 能となったが，両上肢の異なる運動が生ずることが問 題となり，その評価を目的に 3 月 16 日当院リ八科に 入院となった。

4. 所 見: 意識清明, 見当識良好. 利き手はエジ ンバラ質問紙法 ${ }^{11}$ にて $100 \%$ 右利き。右片麻痺はある も, 上下肢とも分離し手指の巧緻性も良好（簡易上肢 機能検査 STEF, Simple Test for Evaluation of Hand Function：右 97 点/100 点, 左 98 点/100 点, いずれも年齢階級別正常範囲). 右手に強制把握を時 に認めた。歩行も杖なしで自立し階段昇降も自立. 表 在知覚, 深部知覚ともに正常. 日常生活動作も入浴を 含め自立.

1) 神経心理学的所見

(1) 半側空間無視：アルバートの線分抹消試験（B 5 用紙）は，右手では，左半側のみすべて無視した。左 手では，無視はなかった。

(2) 触覚認知：はさみ，鍵，コイン，めがねを使用. 右上肢では呼称可能. 左上肢ではすべて不能なるも, 再度触わると再認（同定）可能. 呼称は不可能.

(3)左手の失行:WAB (Western Aphasia Battery）VII. 行為の項目で検査. 右手: $54 / 60$, 左手 : $38 / 60$ から左手の観念運動失行を認めた. 左手の観念 運動失行は模倣でも顕著にみられた。また言語命令で 数種の手の形（きつね, グー, パー, 三本指など）を 作る課題では, 左手に扔いて, 患者は左手を終始, 視 覚的に確認しながら時間をかけるとぎこちなく作るこ とができた．しかし視覚的確認を除去（閉眼，もしく は左手をみさせない) させると，全く課題は遂行でき ず，左手は不動であった。
(4) 右手の強迫的道具の使用: 検查場面で, 右手は 机上の物品に意思とは無関係に触れてしまう，また臨 床場面では電灯のスイッチをどうしてもはじから押し てしまうといった右手の強迫的道具の使用現象を認め た.

(5) WAIS-R (Wechsler Adult Intelligence Scalerevised）：言語性 IQ 87. 動作性 IQ を施行するにあ たっては, 片手動作とし, 非使用手はポケットの中に 入れ, 検査対象物品は右手使用のときは患者の右側 に, 左手使用のときは, 患者の左側におき, 半側空間 無視の影響をなるべく少なくするようにして施行し た. その結果, 右手動作での動作性 IQ 47, 左手動作 での動作性 IQ 72.

(6) WMS-R (Wechsler Memory Scale-revised) の 中の言語性対連合は $2 / 60$, また視覚性対連合は $2 / 60$ といずれでも短期記憶の障害が示唆された。

(7) キメラ図形（図1): 向かって右に男の子，左に 女の子のキメラの図を 2 秒間提示し，何を見たかと質 問すると男の子と答えた。それ以外のものは見ていな いと答えた. 30 秒後に, 男の子を患者の左に, 女の 子を患者の右に提示し, 各々を充分認識させた上で, 先に見たものを質問すると「こちらです」と右手で男
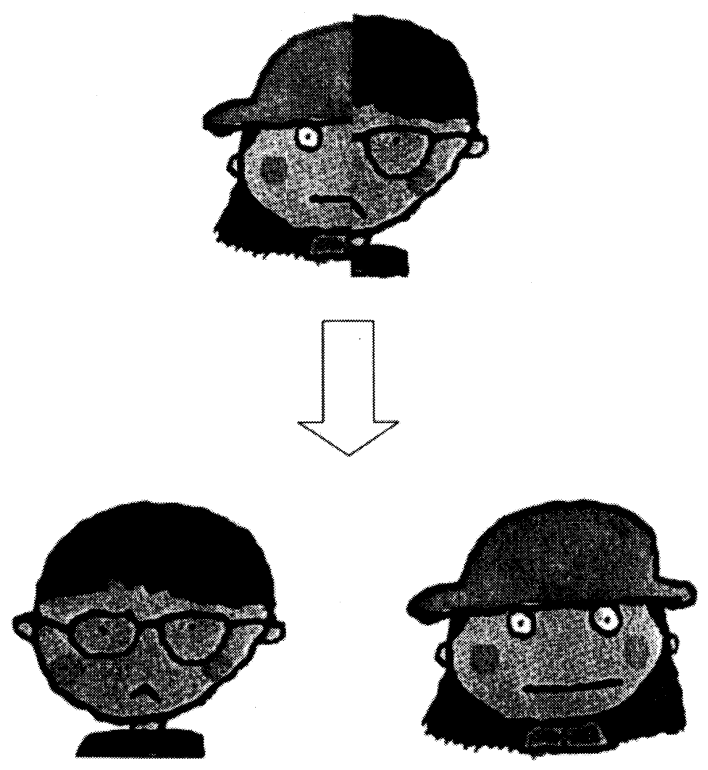

図 1 キメラ図形

向かって右の男の子, 左に女の子のキメラ図形を 2 秒間提 示し，何を見たのかと質問した。また， 30 秒後に，ぞち らでしたかと, 各々の完全な図を提示して, 左右別々の手 で選んでもらった。 

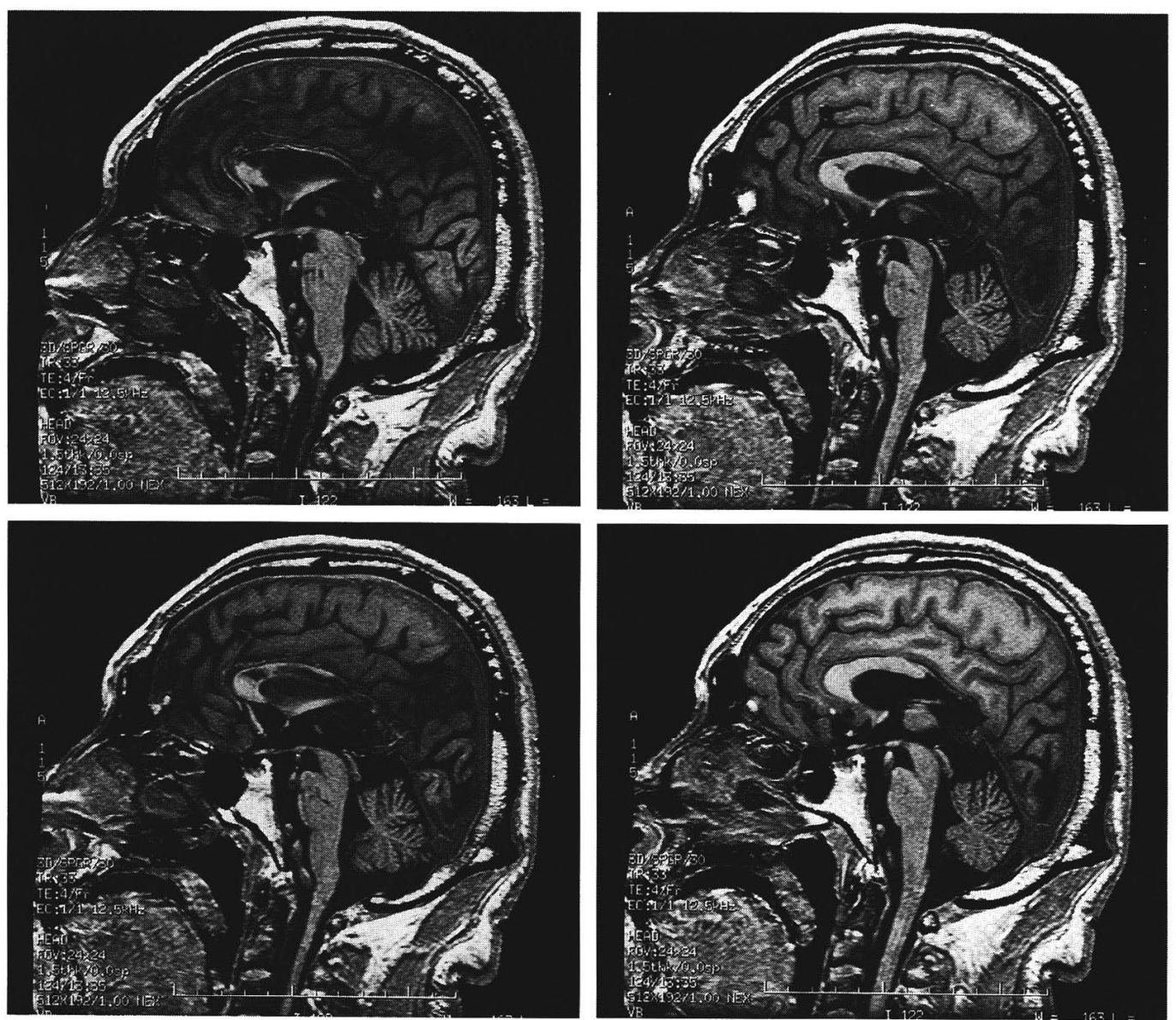

図 2 頭部 MRI

脳梁は吻部および膝部の一部を除き, 全域にわたって損傷を受けている.

の子を指した．しかし，そのとき左手は，右手を抑え ようとし，女の子を指そうとした。患者に右手はしま うように指示すると，男の子ですと言いながらも左手 は女の子を指した．「あなたは，自分の意思で男の子 と思っているのですか」と問うと，「そうです。女の 子のことは知りません」と答えた。 以上のキメラテス トは，他のキメラ図（猫と犬の顔図，サルとパンダの 顔図，男成人と女成人の顔図）でも再現性をもって同 様の結果であった。

2）頭部 MRI（図 2）：脳梁は吻部と膝部を一部残 し，その後方は全域にわたって損傷を認めることか ら, 左右の大脳半球を結ぶ交連線維は吻部と膝部の一 部のみであったままた，左帯状回の一部にもまだら状 に損傷を認めた。他の大脳半球には左右とも異常所見 を認めなかった。
3）頭部 MRA（図 3）：左前大脳動脈の分枝である 左脳梁辺縁動脈の狭窄を認めるも，閉塞所見は見られ なかった。

4）眼底タキストスコープ2)による検査：右目の眼 底網膜の黄斑部の左右に別々に漢字，カナ，それぞれ 8 単語ずつ投影（120 msec）したところ，その単語の 音読は, 左側網膜への刺激では, 漢字で全単語可能, カナで 6 単語可能であったが，右側網膜への刺激で は，漢字，カナともすべて不可能であった。また右大 脳半球の読解能力を調べる目的で, 右側網膜に漢字, カナ，それぞれ 8 単語ずつ投影 $(120 \mathrm{msec})$ し，左 手でその単語に相当する絵を指すように命じたとこ ろ, その正答数は, 1 回目：漢字単語 $1 / 8$, ひらがな 単語 $2 / 8,2$ 回目: 漢字単語 $1 / 8$, ひらがな単語 $2 / 8$ であり, 右大脳半球での読解は困難であった。 

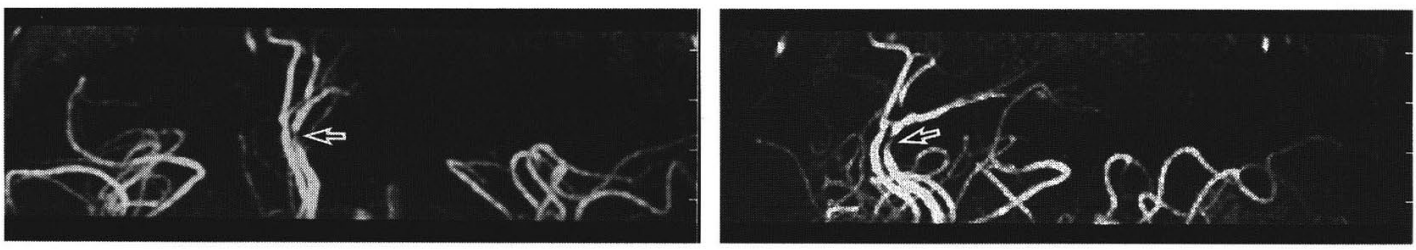

図 3 頭部 MRA

左前大脳動脈の分枝の左脳梁辺縁動脈の狭窄（矢印）を認めるも, 閉塞所見は見られなかった。

\section{経過}

病棟生活および外泊にて日常生活動作を確認した。 $\mathrm{ADL}$ 上は入浴を含め自立していた。しかし時に，夕 オルをかける，部屋の電気をつけるなどの動作では, タオルが右手から離れない, 右手が勝手にタオルをつ かんでしまう，ボタンをすべて押してしまうなどの行 為がみられた。また，左手は意思の動きに反し，ズボ ンのベルトを閉めようとしているのに, 左手がベルト を抜く，新聞を読んでいても，左手がページをめくっ てしまう, 物を両手で取ろうとしても, 左手が遅れる などの動作が時にみられた．特に，精神的緊張時に， 左手の意思に反する動作と上記のような右手の強迫的 使用行為がみられた。 そこで, 以下のような教示を行 つた。

1）動作時には，一息おくこと，複雑な動作の前に は十分リラクセーションを図ること。

2）左手を机の下で柱に握らせ，使用しないように すること.

3）十分習得している動作を中心に行うこと.

4）左手は, 失行検査の際に, 視覚的フィードバッ クにて動きが全く停止したことから示唆されるよう に，左手を使用するときは，常に視覚的確認を行うよ う指導した。

患者は, 両手動作の時は, 深呼吸をする, 肩をリラ ックスさせる，閉眼するなどを行い，心を落ち着ける ようになった。そして新規な動作は極力避け, 習慣化 された日常動作のみを常に視覚下で反復施行すること で, 拮抗する手の動きは減り, 4 月 14 日, 自宅退院 とした。復職能力は実際に自営する家業を長男の監督 下で確認した。当初は, 実際の鋳物業としての行為は 控え，社員や訪れる客への会話，対応には全く問題が なかったので, 接客のみを社長として行うようにし た。その後， 7 カ月間，外来にて経過を観察したが，
両上肢の異常な運動はその頻度が減少し, 仕事で使用 する両手操作によるフォークリフトの運転も可能とな つた.

発症後ほほ 1 年が経過した平成 13 年 3 月 4 日に再 度, 神経心理学的検査の一部を試みた。言語命令で数 種の手の形（きつね, グー, パー, 三本指など）を左 手で作る課題では, 当初, 左手は視覚的確認を除去 (閉眼, もしくは左手をみさせない) させると全く課 題は遂行できず, 左手は不動であったが, 発症 1 年が 過ぎ，充分な形は作れないもののなんらかの動き（き つねがグーであったり，三本指が一本であったりし た）が出現するようになった。 また半側空間無視検査 (アルバートの線分抹消試験) では，両手とも無視を 認めなかった。日常生活の中でも両手の拮抗動作は消 失した。

\section{考察}

一般に, 脳梁への血流供給は，吻，膝，幹部は，前 大脳動脈の分枝である脳梁正中動脈 (median callosal artery）と脳梁周囲動脈（pericallosal artery） により，膨大部は後大脳動脈の分枝である後脳梁周囲 動脈により行われる3). したがって, 前大脳動脈やそ の分枝の閉塞では脳梁の前方部のみに損傷が限局する ことが多く ${ }^{4)}$, 本例のように，膨大部までに損傷が及 ぶ例は，我々が渉猟した限りでは, Lansberg らが報 告した 1 例のみであった ${ }^{5}$. 本例の MRA から推察す ると, 脳梁辺縁動脈には再開通の所見を認めるものの 動脈硬化性変化が著しく，一方，吻部と膝部は一部残 存していることから, 責任血管は脳梁辺緑動脈もしく は脳梁周囲動脈であると考えられた。

本症例は, 発症から 1 週間, 自発開眼があり意識清 明であったが，不動で発語が全くない状態，いわゆる 無動性無言を示していた。中島は，27 例の前大脳動 脈梗塞の中で $30 \% に こ の$ 症候を認めたと報告してい 
る6).また Lechevalier らは，この症候は左右の大脳 半球が急激に連絡を絶たれたことに起因するのではな いかと述べている7). 本症例では左帯状回にもまだら 状の損傷が見られたが，通常帯状回の病巣による無動 性無言は両側の損傷を伴うので8), 本例の無動性無言 は脳梁の損傷を示唆する症候と考えられる。

また当院入院時の主訴は, 左右の手の意思に反する 運動障害であったが，その内容は左右で異なってい た.臨床所見および各種の神経心理学的検查から，右 上肢には，道具の強迫的使用と強制把握，右手の半側 空間無視，右手の構成失行が観察された。日常動作に みられた右手の対象物に対する意思に反する運動には 強制把握の要因も考えられたが，ボタンを全部押して しまうなど，物品に対する強迫的使用の要因が大きい と考えられた。一方，左上肢には，観念運動失行と自 分の意思に反する行為がみられた。さらに両手は，検 査場面や日常場面で拮抗する動きを示した．田中は， 過去の文献考察9 加ら，拮抗失行を「右利き患者にお いては右手の随意運動に触発されて生ずる左手の異常 行動」と定義しているが，本例でも，左手が意思に反 する拮抗動作を行うという点で共通していた。さらに

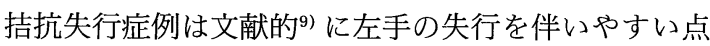
から両者の病態は一部重複しているのではないかと考 えられた。しかし右手に見られた道具の強迫的使用 は，前頭葉内側面を責任病巣とする報告も多く，本例 での左前頭葉帯状回にまだら状梗塞巣も見られたこと から，脳梁梗塞との関連は明らかではなかった。

WAIS-R の検査では, 動作性知能を検査する際に は，使用する手を片手に統制して行ったが，明らかに 左手での施行の方が成績が良好であった。積木課題で は特に右手使用時は, 問題 1 から不可能であったのに 対し，左手使用では問題 6 まで可能であった。この結 果は, Bogen らの分離脳患者での結果 ${ }^{10)}$ と一致し, 積木課題に代表される視覚的立体構成能力が，右脳に 優位であることを示していると思われる。一方，左手 では，口頭命令でも模倣でも動作が困難で，さらに左 手を見ないで動作をさせようとすると，全く左手は動 かなくなったことから，行為における視覚的フィード バックの重要性が示唆された。

キメラ図形テストでは，Sperry, Levy らが分離脳 患者に行ったキメラ図形による実験 ${ }^{11}$ を，タキスト スコープによる瞬間露出ではなく，通常の視覚提示 （2 秒間）で施行した。本例では，男女の顔が半分づ
つあるキメラ図形の, 左大脳半球に入力された右側の 図形のみを患者は知覚しているので，その後に男の 子，女の子が別々に提示されても，これらはキメラ図 形ではないので，各々を充分に認識でき，右手で先の 知覚した図形（つまり男の子）を選び指し示した。し かし，左手は左側の図形（つまり女の子）を指そうと して右手と拮抗した，Levy らの実験では，左手は本 例と同様に左側図形を指そうとしたが，右手も左側図 形を指す傾向があったことは本例と異なっている．本 例でのキメラ露出が，Levy らの場合よりも長かった ために，充分な意識的知覚が扔きたためではないかと 推察された。また，本テストでは，患者は，右大脳半 球に入力された図形を決して自覚することはなく，む しろ否定している。この事実は分離脳患者でも同様で

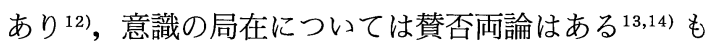
のの, 言語化されるような意図動作については左脳に 局在するのではないか，また言語化されないと（左大 脳半球に到達しないと）意識の上に上らないのではな いかと考えられた．また日常の動作にても，左手は意 図とは反する行為を行う傾向があることも，このこと を示唆していると思われる。

脳梁梗塞に起因する左右の上肢の運動障害について のリハアプローチの報告は極めて少ない，林らは，多 発性脳梗塞に合併した脳梁梗塞症例の失行症状に対 し, (1) 正常な運動感覚を入力すること, (2) 心理的緊 張は症状発現の誘発因子となるので不安を和らげるこ と, (3) 左手に失行が現れたときには一度その動作を 中断すること, (4) 言語指示よりもセラピストの誘導 のほうが効果があることなどを報告した ${ }^{15)}$ 。一方，種 村らは，同様の拮抗失行に対し，患者自身が自分の言 葉で行為の統制を図るように指導し，よい結果を得た と述べている16)．本症例においても，精神的緊張時や 意図的動作では，拮抗失行や道具の強迫的使用が発現 しやすいので，深呼吸や肩の体操をして，リラクセー ションを患者自らが図るように指導した。また左手の 観念運動失行は，左手を見ないで行うと全く運動が停 止したことから，視覚的フィードバックの重要性が示 唆され，両手の行為は常に視覚下で行うょうにした。

本症例は発症後, 7 力月が経過し, 失行症状も両上 肢の拮抗する運動障害もかなり減少した．文献的に も, 前大脳動脈領域の梗塞に起因する場合, その症状 は確実に減っている $5,15,17)$. その回復機序には, 脳梁 内の残る線維の代償が考えられるが，脳梁を完全に切 
断した分離脳例でも改善がみられることから，手が同 側性の大脳半球により支配され始めた可能性もあ る ${ }^{18)}$. しかし，梗塞例による脳梁離断でも，山鳥は， 片手だけの症状は意外に回復しやすいが，半球病巣が 加わると回復が不良となることを指摘している ${ }^{19}$. 本 例では, 病巣はほぼ脳梁に限局し, 大脳半球病巣は, 左带状回にまだらにわずか存在するのみであった。さ らに発症後 1 年が経過し，日常生活は完全に自立した 上に，仕事としてのフォークリフトの両手運転も可能 となっている.

\section{文献}

1) Oldfield RC: The assessment and analysis of handedness: The Edinburg Inventry. Neuropsychologia $1971 ; 64: 236-247$

2) Sugishita M, Hamilton CR, Sakuma I, Hemmi I: Hemispheric representation of the central retina of commissurotomized subjects. Neuropsychologia $1994 ; 32: 399-415$

3) Kakou M, Velut S, Destrieux C: Arterial and Venous Vascularization of the corpus callosum. Neuro-Cirurgie $1998 ;$ 44:31-37

4) Chrysikopoulos H, Andreou J, Rossakis A, Pappas $\mathrm{J}$ : Infarction of the corpus callosum: computed tomography and magnetic resonance imaging. Eur J Radiol $1997 ; 25: 2-8$

5) Lansberg H, Göttert R, Münßinger U, Boegner F, Marx P : Callosal disconnection syndrome in a lefthanded patient due to infarction of the total length of the corpus callosum. Neuropsychologia $1999 ; \mathbf{3 7}$ : 253-265

6) 中島健二: 前大脳動脈閉塞. 脳神経 $1990: 42: 821-$ 834

7) Lechevalier B, Bertran F, Busson P, Chapon F, Raoul G, De La Sayette V: Akinetic mutism with right hemiplegia caused by infarction in the territory of the left anterior cerebral artery. Rev Neurol 1996 ; 152 : 181-189

8) Barris WA, Schuman HR: Bilateral anterior cingulated gyrus lesion, syndrome of the anterior cingulated gyri. Neurology $1953 ; 3: 44-52$

9）田中康文：拮抗失行およびその類縁症候. 神経進歩 1991; 35 : 1015-1030

10) Bogen JE: The other side of the brain I : Dysgraphia and dyscopia following cerebral commissurotomy. Bull Los Angeles Neurol Soc 1969; 34 : 73105

11) Levy J, Trevarthen C, Sperry RW : Perception of bilateral chimeric figures following hemispheric deconnection. Brain 1972; 95 : 61-78

12) Sauerwein HC, Lassonde M: Neuropsychological alterations after split-brain surgery. J Neurosurg Sci $1997 ; \mathbf{4 1}: 59-73$

13）杉下守弘：左脳と右脳の対話. 青土社, 東京, 1990 ; pp 238-257

14）前田真治, 長澤 弘, 正木かつら, 古橋紀久, 後藤安恵： 脳梁出血例にみる意図的行動の制御。失語症研究 $1995 ; 15: 264-269$

15）林 恵子, 藤縄光留, 新井和香奈, 冨田昌夫, 棣沢達志, 萩野 裕, 野々垣学: 脳梁離断症状を呈する患者への リハビリテーションーその具体的なアプローチを巡っ てー． 神奈川リハビリテーションセンター紀要 1999 ; 25: $26-31$

16）種村留美, 種村 純, 重野幸次：離断症候群の症例に対 する言語的行動調整の試み. 作業療法 1991；10：139145

17）畑 隆志，鈴木秀一：離断症候群とリハビリテーショ ン. 総合リ八 $1988 ； \mathbf{1 6}: 869-878$

18）杉下守弘：脳梁切断例（Split-brain）加らみた大脳半 球の Lateralization. 神経進歩 $1980 ； 24: 565-579$

19）山鳥 重: 高次脳機能障害の理解のために. OT ジャ ーナル 1993；27 : 57-62 